\title{
AESTHETICS AS POLITICS: REFLECTIONS ON AN ARCHITECTURE OF DISSENSUS
}

\section{A B S T R A C T}

Contributing to the debate for a democratic articulation of the urban environment, this paper focuses on the reinterpretation of the relation between thinking and perception in Kant's Second Moment of the Analytic of the Beautiful, by Jacques Rancière. Rancière argues that the dissensual operation implied in Kant's definition of the beautiful involves a superimposition that transforms the given form or body to a new one. Social emancipation for Rancière becomes an aesthetic matter, a matter of dismemberment of a body animated by a particular belief. When the loss of destination implicit in aesthetic experience, as explained by Rancière, disrupts the way in which bodies fit their functions in a social order, then a political effect is produced. The aesthetic effect presupposes dis-identification. Within the aesthetic community, political subjectivisation is based on a dis-identification process. Furthermore, reconsideration of modernity for Rancière means going back to Schiller's idea of the aesthetic education of man which originated in Kant's Analytic of the Beautiful. We can argue with reference to an architecture of dissensus that through a process of dislocation, dismemberment and dis-identification, tradition opens up to a constant transformation to something new, involved in a never-ending play between totally different layers that make up everyday experience.

Helen Tatla

KEY WORDS

Technological Educational Institution of Athens
AESTHETICS

POLITICS

DISSENSUS

BEAUTIFUL

PLAY

ARCHITECTURE 


\section{INTRODUCTION}

Refuting Jurgen Habermas's idea of democracy founded on a rational, consensus-oriented dialogue, Jacques Rancière points on the impossibility of rational deliberation that is free from power. He insists that disagreement in democratic politics is a power-based misunderstanding between poor and rich with regard to a more equal distribution of the sensible. Rancière's turn from language to materiality permits him to interpret misunderstandings as being beyond language and yet related to the possibility to speak as such. With this approach, by addressing the mechanisms through which the domain of sensual experience is divided, Rancière contributes to the crucial discussion concerning a viable urban reality related to transnational politics and the operation of democracy today. He suggests an egalitarian political practice, through which the given division of urban sensible experience can be disrupted by individuals who cannot legitimately speak. ${ }^{1}$

It is apparent that dissensus design can take different forms which can vary from a decision not to intervene in an existing built environment, to an explicit challenge to the established order of space. In opposition to a consensusoriented design, the partition of the sensible that comes out in this way is not a new spatial ordering, but rather a new ordering of thought which aims to a perpetual questioning of the limits which define the aesthetic appropriation of things in the built environment. Investigating the concept of dissensus in the core of the Kantian beautiful, this paper includes three parts: The first deals with Rancière's approach to the Aristotelian mimesis and his interpretation of Kant's Second Moment of the Analytic of the Beautiful, the second focuses on the aesthetic dis-identification as a precondition for political subjectivisation and the third explores the in-between space between thought and perception in terms of the Schillerian conception of play.

THE KANTIAN BEAUTIFUL UNDERSTOOD IN TERMS OF DISSENSUS

Initiating an innovative approach to the relation between thinking and perception or between aesthetic pleasure and concept with reference to Kant's Analytic of the Beautiful, Rancière insists on the meaning of modernity as fundamentally aesthetic. He uses the term "dissensus" in order to signify the ontology of the rupture between aesthetic pleasure and concept which he identifies in Kant's Second Moment of the Analytic of the Beautiful.

In order to elucidate Rancière's approach, we will start with a brief account of his analysis on mimesis. Rancière understands mimesis and representation as a "regime of concordance between sense and sense". ${ }^{3}$ The ability of art to 
unite people through sensation is basic in Rancière's approach. The conception originates in Deleuze's approach to sensation. ${ }^{4}$ Departing from Aristotle, Rancière considers the theatre as the site of manifestation of this twofold harmonic relation, which involves poiesis and aisthesis. Poiesis deals with the exhibition of signs that could be read without ambiguity, while aisthesis concerns the thoughts and emotions by which the play is felt and understood. Their concordance implies continuity between the intrinsic consistency or autonomy of the play and its capacity to produce ethical effects in the minds of the spectators.

As early as 1750 , the consistency of this model was called under question by Rousseau. In his Letter to D'Alembert on the Theatre, Rousseau questions the direct line between performance and the mind of the spectator, with reference to Moliere's Misanthrope. Going further back, Rancière asks how theatre can unveil a hypocrite, since hypocrisy is its very essence. Twenty-three years after Rousseau, Schiller, in his Robbers, breaks with the idea that nature sustained the coincidence between performance and its ethical efficacy in the minds of the spectators. The consequent rupture in the harmony between performance and the spectator or between poiesis and aisthesis is the very meaning of the term "aesthetics", Rancière argues. Rousseau counter-poses to the play of the hypocrite the Greek civic festival, while Plato opposes the ethical immediacy of the chorus to the passivity of the audience in a theatre. ${ }^{5}$

Rancière insists that it is this rupture in mimesis what Kant conceptualized in his definition of the beautiful as "what is presented as an object of universal delight apart from any concept". ${ }^{6}$ Rancière rejects any equation of Kant's definition with the traditional definition of beauty as harmony. He also fiercely opposes to the connection of this rapture to Kant's definition of the sublime. He identifies the radical break with representation not in Kant's conception of the sublime but in the phrase "apart from any concept". It leaves no place to any relationship between the concepts of artistic poiesis and the forms of aesthetic pleasure, between poiesis and aisthesis, Rancière argues. Thus art as a creative procedure involves concepts, while the feeling of aesthetic pleasure excludes concepts. Free appearance is offered to the free play of art. Free appearance is the product of a dissensual operation in a community, Rancière claims, between two sensoria. The sensorium of poiesis and the sensorium of aisthesis.

In order to support his interpretation of the Kantian beautiful as rapture, Rancière recalls Winckelmann. In his History of Ancient Art, published twenty-six years before Kant's Critique of Judgement, Winckelmann has selected a crippled and beheaded statue, known as the Belvedere Torso, as the masterpiece of Greek art. The paradox is intensified by the fact that Winckelmann considers the statue as a representation of Hercules. ${ }^{7}$ Rancière finds an analogy between 
the Belvedere Torso and the Deleuzian "body without organs". ${ }^{8}$ He considers Deleuze's approach to Bacon's athletic figures in his Logic of Sensation as an heir to the Schillerian conception of liberty that has disappeared as the political liberty of people. On this ground, he criticizes Deleuze's insistence on the sublime dramaturgy. He argues that the dissensual operation implied in Kant's definition of the beautiful involves a superimposition that transforms the given form or body to a new one. In a process of subtraction and addition, Winckelmann reinvents with his words the shape and meaning of Greek statues. In this way, the Belvedere Torso or Bacon's mutilated figures could evoke a new sense of community. ${ }^{9}$

Rancière recognizes a similar process of subtraction and addition to modern choreographers, poets and theatre directors. He mentions Adolphe Appia's miseen-scène of the Wagnerian operas, where Appia places the characters in a space of geometric modules, in a way that their bodies look like statues to be molded by lightening. ${ }^{10}$ Similarly, we could argue referring to an architecture of dissensus that it implies a process of subtraction and addition, through which tradition opens up to a constant transformation to something new. It involves a neverending play between totally different layers that make up everyday experience.

Architecture has to follow the logic of the dissensual operation, which can be best expressed according to Rancière by the art of mise-en-scène, because it embodies "the way in which sensory presence and ethical immediacy, opposed to representational mediation, are transformed, thwarted and eventually overturned by the powers of subtraction and disconnection of the statue, the words and the shadows." ${ }^{11}$ A work that come out in this way, does not have to conform either to the modernist "truth to the medium" or to the Deleuzian "pure sensation", he says. He claims that what he calls "the ontology of the dissensual" is just a play of aesthetic ideas and in this way a "fictional ontology", an ontology which operates as if it had a different texture from the sensations that make up everyday experience. The aesthetic work that comes out in this way is a substitute to the work that realizes the law of the medium or that of pure sensation.

\section{AESTHETIC DIS-IDENTIFICATION AS A PRECONDITION FOR POLITICAL SUBJECTIVISATION}

Rancière refers to the example of the museum in order to elucidate the meaning of dissensus further, in relation to everyday experience. In the museum the works are taken away from their original destination and the specific community in which they belonged. In the new environment there is not any boundary separating what belongs to the realm of art and what to the realm of everyday 
life. All representations are offered to the same indifferent gaze. Aesthetic separation does not imply a private paradise for amateurs or aesthetes, claims Rancière. This is why Schiller after reading Kant's Third Critique could not conceptualize of a community united by the vision of eternal beauty, he insists. The aesthetic effect is in fact a relationship between two "separations". Before entering the realm of aesthetic experience in the museum, the works had been produced for a particular destination: festivities and religious ceremonies, building decorum etc. The entering in the aesthetic sensorium of the museum is marked with the loss of destination. Along with the loss of the harmony between poiesis and aisthesis, the relation between each work and its particular place in the social order, identified with relations of dominance and inequality, has also been lost in the museum's environment. The meaning of the word loss here is different from the loss of the aura as its unique relation in space and time, to remember Benjamin. ${ }^{12}$ Social emancipation is not related to the mechanical reproduction of an archetype. Social emancipation for Rancière becomes an aesthetic matter, a matter of dismemberment of a body animated by a particular belief. ${ }^{13}$

When the loss of destination implicit in aesthetic experience, as explained by Rancière, disrupts the way in which bodies fit their functions in a social order, then a political effect is produced. It consists in "a multiplicity of folds and gaps in the fabric of common experience that change the cartography of the perceptible, the thinkable and the feasible". ${ }^{14}$ The political effect Rancière claims, occurs under the condition of an original disjunction, which separates cause and effect. The aesthetic effect presupposes dis-identification. Within the aesthetic community, political subjectivisation is based on a dis-identification process.

Rancière attempts to show the relation of "dissensus" to art and life by using three propositions. ${ }^{15}$ The first proposition, "Séparés on est ensemble", which he translates "Apart we are together", is a poetic statement quoted from Mallarmé's prose poem "The White Water Lilly". The poet makes a short boat trip in order to see a lady, but when he hears the faint noise of footsteps, he decides to leave the secret of their "being together" intact and departs. The second proposition deals with the project "Campement Urbain" (Urban Encampment), conceived by a group of French artists, which engages with the public space of one of the most wretched outskirts of Paris, where riots erupted in 2005. ${ }^{16}$ The project was to create a place "extremely useless, fragile and non-productive" a place of solitude that could be occupied by one person at a time. The project was discussed with any resident who wanted to get involved. The third proposition is a quotation from Deleuze and Guattari's book What is Philosophy? It concerns the ability of art to unite people through sensation. The work of the artist is to wrest percepts and affects from the perceptions 
and affections that make up the fabric of ordinary experience. Through the operations of twisting, seizing and rendering art weaves a community together, claims Rancière. In Deleuze and Guattari's words:

"This is precisely the task of all art and, from colours and sounds... (it) extract(s) new harmonies, new plastic or melodic landscapes, and new rhythmic characters that raise them to the height of the earth's song and the cry of humanity. (...) The success of a revolution resides... precisely in the vibrations, the clinches, and openings it gave to men and women at the moment of its making and that composes in itself a monument that is always in the process of becoming... "17

The three propositions mentioned above, define, according to Rancière, a specific kind of community, a community of sense, a sensus communis. It suggests three forms of community. At a first level, a community of sense is a combination of sense data and a combination of different senses of "sense". However, the three propositions mentioned above, share in common the staging of a conflict between two sensory regimes or two sensory communities. It concerns the superimposition of one sensorium upon another. For instance, the sensory reality (the boat, the river etc) suggested by Mallarmé - first sensorium, neutral - is a metaphor for his poetic activity - second sensorium, carrier of artistic power. This is the meaning of dissensus, Rancière claims. The suspension of the fragile and non-functional architectural construction above the poor suburb also manifests a dissensual relationship. At a second level, the philosopher provides the conceptual frame for the tension between the two sensory worlds. And at a third level, the assemblage of sensory data and the intertwining of contradictory relations established by art, are intended to produce a new form of community. The construction of the solitary place aims at creating new forms of socialization and a new awareness of everyone's own capacity. The new forms of the community have already been actualized by collective discussion concerning the design of the place. The artwork refers to the future; it is a monument to the people to come, a monument to its absence. The artistic "dissensual community", a community structured by disconnection has a dual operation: as a means for producing an effect and as the reality of that effect. ${ }^{18}$

Investigating aesthetic disconnection in the sense of "being together apart", as an expression of the autonomy of art, within modernism and postmodernism, Rancière distinguishes the modernist approach which loosely connects the work to a future community, from the postmodernist for which "being apart" turns to an "aristocratic illusion" aiming to reject the reality of "being together"; moreover, he distinguishes the aesthetic of the sublime in which "being apart", by fear of heteronomy, turns into an absolute heterogeneity. ${ }^{19}$ 


\section{INVESTIGATING THE INTERMEDIATE SPACE BETWEEN THINKING AND PERCEPTION}

On the basis of the concept of "dissensus", Rancière coins the term "aesthetic regime of the arts", in order to denote the political essence of the conception of the aesthetic in modernity. The meaning of the term aesthetics for Rancière does not refer to a theory of art in general as a theory of taste or sensibility. It refers to a specific mode of being of the objects of art, a specific regime for identifying and reflecting on the arts. Artistic phenomena are identified by an aesthetic regime which, freed from all its ordinary relations, is inhabited by a heterogeneous power, the power of a form of thought, that has become foreign to itself. This implies a transposition between the activity of thinking and the perception of the aesthetic. Rancière considers Schiller's aesthetic state as the manifesto of his conception of modernity as the "aesthetic regime of the arts" as far as it indicates a special identity of opposites between thinking and art's perception or between life and the autonomy of art. As Rancière claims on the basis of his approach to Kant's Analytic of the Beautiful, the aesthetic state is a pure instance of suspension, a moment when form is experienced for itself. Art's autonomy is defined by him in this way. ${ }^{20}$

The rejection of the concept of mimesis by modernity, Rancière claims, implies art's liberation from specific rules and specific hierarchy, subject matter and genres. The aesthetic regime is identified by destroying the mimetic barrier that separated the way of doing and making of the arts from the order of social doings. The aesthetic regime defends the absolute singularity of art and simultaneously it destroys every pragmatic criterion for isolating this singularity. Thus it sets the foundations of the autonomy of art and identifies the forms of art with those which life uses to shape itself. ${ }^{21}$ With reference to the autonomy of the work, Rancière shares Adorno's aversion to any form of assimilation of art into life and his persistence on the radical separation of the work from aestheticized commodities. He however opposes to Adorno's conception that the work has to become even more mechanical and "inhuman" in relation to mass consumption, in order to denounce the capitalist division of work and the embellishments of commodities. Rancière claims that it is against its autonomy. ${ }^{22}$

In his writings On the Aesthetic Education of $\mathrm{Man}^{23}$ Schiller asserts that domination and servitude constitute, at first, part of an ontological distribution, the activity of thought against the passivity of sensible matter. Nevertheless, Schiller identifies an in-between situation, a situation of dual cancellation, where thought and perception become one and the same reality. This indicates a new region of being, the region of free play and appearance, which, Schiller insists, makes the conception of equality possible. Schiller's concept of aesthetic 
education, Rancière claims, aims to train men in this particular form of living in a free political community. Consequently, a new meaning of political revolution was produced by Schiller's conception of an aesthetic revolution. It is best expressed in the "Aesthetic programme" of German romanticism, a rough draft written in common by Hegel, Hölderlin and Schelling. It deals with the fusion of pure thought and life in the material expression of the unconditioned freedom of pure thought. The meeting of the new paradigm for aesthetic autonomy with the Marxist revolution and its consequent failure to lead to a political revolution resulted to the appearance of Surrealism and the Frankfurt School on the one hand and postmodernism on the other, Rancière insists. ${ }^{24}$

Considering postmodernism in particular, Rancière argues that its desperate attempt to establish art's autonomy through a historical rapture, was in fact useless, since this does not differ from modernity conceived as the aesthetic regime of the arts. However, the situation soon turned out to be a challenge to art's autonomy. This suggests either to go back to the beginning or original separation. And while reconsideration of modernity for Rancière means going back to Schiller's idea of the aesthetic education of man which originated in Kant's Analytic of the Beautiful, the postmodern reversal has as its theoretical basis Lyotard's reinterpretation of the Kantian Analytic of the Sublime. Consequently, critical tradition was transformed into a thinking of mourning and regression. Rancière claims that Kant had placed art beyond the sublime feeling, in order to make it a witness to the encounter of thought with the unrepresentable that cripples all thought; a witness for the prosecution against any aesthetico-political utopia of thought-becoming-world..$^{25}$ In this way, Rancière overcomes the sovereignty of reason implicit in Lyotard's understanding of the Kantian sublime.

If the notion of modernity has a meaning in the frame of the aesthetic regime of the arts, proposed by Rancière, this does not deal with aesthetic innovation as such, but with the invention of aesthetic forms and material structures referring to a life to come. This is what aesthetic avant-guard believed to have brought to political avant-guard, or at least tried to: the transformation of politics into a total life programme through an aesthetic appreciation of reality based on sensation. Aesthetics understood in this way, does not suggest a philosophical discourse aiming to dominate art or architecture. Rather it suggests an attempt to activate thinking by pointing to the work's paradoxes and contradictions. Thus, an architecture of dissensus implies dislocation, dismemberment and dis-identification of the work, while it still remains within the spectrum of the Kantian indifferent gaze. As such, it contributes to a perpetual free play between thinking and perception conceived as equals. In this way, architecture opens up its limits to other art species and perceptual means, while it participates in a political operation in terms of autonomy and equality. 
See for instance: Jurgen Habermas, The Theory of Communicative Action, trans. Thomas MacCarthy (Boston: Beacon Press 1984); Jacques Rancière, Dissensus. On Politics \& Aesthetics, ed. \& trans. Steven Corcoran (London: Bloomsbury, 2010).

For the presentation and critical discussion of an urban development project aiming at an alternative development process on the basis of Rancière's philosophy, see: Camillo Boano \& Emily Kelling, "Toward an Architecture of Dissensus: Participatory Urbanism in South-East Asia," Footprint, Delft Architectural Theory Journal, Delft University of Technology, 13 (2013): 41-62, ISSN 1875 1504, accessed July 17, 2015, doi: http://dx.doi.org/10.7480/footprint.7.2.769. The project includes the Thai programme Baan Mankong (secure housing) and its regional counterpart Asian Coalition for Community Action (ACCA). As the writers of the article explain, "people that were previously ignored and marginalized are engaged at the centre of a process of transforming their lives, spaces and position in the city."

Jacques Rancière, The Emancipated Spectator, trans. Gregory Elliott (London: Verso, 2009), 60ff. Gilles Deleuze \& Fellix Guattari, What is Philosophy, trans. Graham Burchell \& Hugh Tomlinson (London: Verso), see 163ff., in particular.

Rancière, The Emancipated Spectator, 60-63, in particular.

Jacques Rancière, The Emancipated Spectator, 64ff. For Kant's Second Moment of the Analytic of the Beautiful, see for instance: Immanuel Kant, The Critique of Judgement, trans. James Creed Meredith (Oxford: At The Clarendon Press, 1969), 50-60.

Johann Joachim Winckelmann, History of Ancient Art, trans. Giles Henry Lodge (Boston: James Munroe \& Co, 1849), Vol. II, 234, in particular.

Gilles Deleuze, Francis Bacon: the logic of sensation, trans. Daniel W. Smith (London: Continuum, 2004), 44ff., in particular.

Rancière, The Emancipated Spectator, 64-67.

Rancière, The Emancipated Spectator, 67.

Rancière, The Emancipated Spectator, 67.

Walter Benjamin, "The Work of Art in the Age of Mechanical Reproduction" incl. in: ed. Hannah Arendt, Illuminations, trans. Harry Zohn (New York: Schocken Books, 1969), 217-251.

Rancière, The Emancipated Spectator, 69-71.

Rancière, The Emancipated Spectator, 72. See further discussion in: 72-73.

Rancière, The Emancipated Spectator, 51-57.

See a discussion on the project "I \& Us" with the members of the Encampement Urbain Group in: Networked Cultures e-magazine accessed July 17, 2015, http://www.networkedcultures.org/ index.php?tdid=64.

Rancière, The Emancipated Spectator, 55. Deleuze \& Guattari, What is Philosophy?,76.

Rancière, The Emancipated Spectator, 57-59.

Rancière, The Emancipated Spectator, 59-60.

Jacques Rancière, The Distribution of the Sensible: Politics \& Aesthetics, trans. Gabriel Rockhill (London: Continuum, 2004), 10, 22ff.

Rancière, The Distribution of the Sensible, 23.

Jacques Rancière, Aesthetics and its Discontents, trans. Steven Corcoran (Cambridge: Polity Press, 2009), 39-41.

Friedrich Schiller, On the Aesthetic Education of Man in a Series of Letters, intr. \& trans. Reginald Snell (N.Y.: Dover Pbl., 2004).

Rancière, The Distribution of the Sensible, 26-28.

Rancière, The Distribution of the Sensible, 9, 28-30. Rancière draws a line between two different conceptions of political subjectivity related to the avant-guard: the archi-political idea of the party, that is to say of a political intelligence which sums up the essential terms of change, and the metapolitical idea of a global political subjectivity, the idea of a potentiality inherent in the innovative sensible modes of experience of a community to come. 
Adorno, Gretel and Rolf Tiedmann. eds, Theodor Adorno, Aesthetic Theory, intr. \& trans. Robert Hullot-Kentor. London: The Athlone Press Ltd, 1977.

Benjamin,Walter. "The Work of Art in the Age of Mechanical Reproduction" incl. In Illuminations, edited by Hannah Arendt, trans. Harry Zohn. New York: Schocken Books, 1969.

Boano, Camillo and Emily Kelling. "Toward an Architecture of Dissensus: Participatory Urbanism in South- East Asia." Footprint, Delft Architectural Theory Journal, Delft University of Technology, 13 (2013): 41-62, ISSN 1875-1504, accessed July 17, 2015, doi: http://dx.doi.org/10.7480/ footprint.7.2.769.

Deleuze, Gilles. Francis Bacon: the logic of sensation, trans. Daniel W. Smith. London: Continuum, 2004.

Deleuze, Gilles and Felix Guattari. What is Philosophy, trans. Graham Burchell \& Hugh Tomlinson. London: Verso.

Habermas, Jurgen. The Theory of Communicative Action, trans. Thomas MacCarthy. Boston: Beacon Press, 1984.

Kant, Immanuel. The Critique of Judgement, trans. James Creed Meredith. Oxford: At The Clarendon Press, 1969.

Lyotard, Jean-Francois. The Postmodern Condition: A Report on Knowledge, intr. Frederic Jameson, trans. Geoff Bennington \& Brian Massumi. Minnesota: University of Minnessota, 1984.

Lyotard, Jean-Francois. The Inhuman, trans. Geoffrey Bennington \& Rachel Bowlby. Stanford: Stanford University Press, 1991.

Rancière, Jacques. The Emancipated Spectator, trans. Gregory Elliott. London: Verso, 2009.

Rancière, Jacques. The Distribution of the Sensible: Politics \& Aesthetics, trans. Gabriel Rockhill. London: Continuum, 2004.

Rancière,Jacques. Aesthetics and its Discontents, trans. Steven Corcoran. Cambridge: Polity Press, 2009.

Rancière, Jacques. Dissensus. On Politics \& Aesthetics, ed. \& trans. Steven Corcoran. London: Bloomsbury, 2010.

Schiller, Friedrich. On the Aesthetic Education of Man in a Series of Letters, intr. \& trans. Reginald Snell. N.Y.: Dover Pbl., 2004.

Winckelmann, Johann Joachim. History of Ancient Art, trans. Giles Henry Lodge. Boston: James Munroe \& Co, 1849 . 
Kompletno istraživanja objavljeno je u knjizi The indispensable excess of the aesthetics: evolution of sensibility in nature (Neizostavni višak estetike: Evolucija senzibiliteta u prirodi, Lexington 2015).

KLJUČNE REČI: EVOLUTIVNA ESTETIKA, DARVIN, BIOSEMIOTIKA, ZOO-POETIKA, AESTHESIS, ZOO-ESTETIKA, EVOLUCIJA

\section{OBECANJE MEDIJSKE ARHEOLOGIJE Nadežda Čačinovič}

Medijska arheologija nudi novi i neophodan alat za suočavanje sa mnoštvom fenomena koje tako neselektivno - anahrono ili na druge načine - prepoznajemo kao umetnost i klasifikujemo kao umetnička dela. Rad pokušava da naglasi razliku u poređenju sa srodnim gledištim: teorije kulturne transmisije, materijalnosti kulture, logike estetskih režima itd. Moglo bi se nazvati "mediji pre medija" (i prati Kitlera (Kittler)) ili kopati sa Zilinskim u "Duboko vreme medija" (Deep Time of the Media) sa dobrom vezom prema "istoriji pristupa čula" ili ići pravo sa Jusi Parikom i Erki Huhtamom (Jussi Parikka, Erkki Huhtamo) i koristiti "medijsku arheologiju”: ali je uvek priznanje protejske prirode umetnosti i arhitekture.

KLJUČNE REČI: MATERIJALNOST KULTURE, ISTORIJA ČULA, MEDIJI, KULTURNA TRANSMISIJA

\section{FORMA I ZNAČENJE U ARHITEKTONSKOJ TEORIJI Jale Nejdet Erzen}

Često je arhitektonska teorija bilo jasno izražena propisanim stavovima o tome šta bi arhitektura trebalo da bude, pre nego stavovima formulisanim od istorijskih iskustava i primera arhitekture. U ovom radu ću pokušati da ponudim čitanje arhitektonske forme gledajući istorijski primer iz klasične otomanske arhitekture i savremene primere, pokazujući kako različite arhitekture tretiraju formu. U primerima Sinanove arhitekture, simboli su istraživani u odnosu na kretanje, urbani sklop, religiju i moć. Ideja je da će ova analiza ponuditi razumevanje značaja arhitekture u okvirima ljudskog iskustva i urbanog konteksta kojii dopire izvan strukture i funkcije.

KLJUČNE REČI: ARHITEKTURA, SINAN, FORMA, ZNAČENJE, STRUKTURA, TELESNI ODNOSI

\section{POL ŠIRBART I UTOPIJA OD STAKLA}

\section{Tyrus Miller}

Ovaj rad će razmotriti arhitektonske spise nemačkog ekspresionističkog pisca Pola Širbarta (Paul Scheerbart), sa fokusom na njegovoj fascinaciji staklom kao arhitektonskim i metaforičkim materijalom. Diskusija je o Širbartovom arhitektonskom traktatu Arhitektura stakla (Glass Architecture), njegovom romanu Siva tkanina (The Grey Cloth) i srodnim tekstovima o arhitekturi stakla. Širbart predstavlja alternativnu tradiciju unutar arhitektonskog modernizma, koja gleda na staklo kao na konstruktivan materijal koji predstavlja modernost kroz izlaganje strukturalnih elemenata, takođe u službi komfor forme prema funkciji. Širbart, nasuprot tome, smatra staklo nosiocem boje i multiplikatora svetlosti, koje je video kao sposobnog da transformiše čovekovu okolinu i ostvari pozitivne efekte na pojedince i kolektive. On je video svetlost kao kulturnoformativnu, a arhitekturu stakla kao sredstvo kojim izgrađeno okruženje može da poveća moderni kulturalni utopijski potencijal. Takođe, ukratko ću razmotriti i uticaj Širbarta na anarhističkog arhitektu Bruna Tauta (Bruno Taut) i na razmišljanja Valtera Benjamina (Walter Benjamin). 
POLITIZACIJA SENZIBILITETA:

EFEKAT SPEKTAKLA KOLONIJALNOG CARSTVA 1930-IH U SEULU

\section{Joosik Min}

Ovaj rad ima za cilj da analizira fenomen potrošačake kulture u smislu efekata spektakla kolonijalnog carstva, koji su bili prosperitet bez presedana 1930-ih u Seulu. Ovaj fenomen se može tumačiti kao politizacija čulnosti. Prostorna promena je pojačala kolonijalnu diferencijaciju grada koji je bio podeljen na Južno selo za Japance i Severno selo za Koreance. Ovo je olakšalo modernu homogenizaciju urbanog prostora. Naročito su robne kuće bile okrepljene kao moćan aparat za potrošački kapitalizam, pozivajući Koreance na japanske ulice, prevazilazeći prostornu granicu kolonijalne segregacije. Manipulacijom izložbenim tehnikama robne kuće, japansko carstvo izgradilo je vizuelno privlačnu sliku, podstičući kolonizovane da iskuse fascinaciju modeme urbane kulture kao gomila ili gledaoci na ulici. Spektakl carstva napravio je nove linije kulturne distinkcije na osnovu diferencijacije društvenog sloja unutar kolonizovane zajednice.

KLJUČNE REČI: EFEKAT SPEKTAKLA, URBANI PROSTOR, KOLONIJALNI GRAD, POTROŠAČKA KULTURA, ROBNA KUĆA, SEUL

ESTETIKA KAO POLITIKA:

\section{MISLI O ARHITKTURI NESLAGANJA}

Helen Tatla

Doprinoseći debati za demokratsku artikulaciju urbane sredine, ovaj rad se fokusira na reinterpretaciju odnosa između razmišljanja i percepcije u Kantovom Drugom trenutku analitike lepog, Žaka Ransijera. Ransijer tvrdi da disenzualna operacija u Kantovoj definiciji lepog uključuje superimpoziciju koja transformiše datu formu ili telo u novo. Društvena emancipacija za Ransijera postaje estetska stvar, stvar raspadanja tela animiranog od strane određenog uverenja. Kada gubitak destinacije implicitan u estetskom iskustvu, kako je objasnio Ransijer, remeti način na koji tela uklapaju svoje funkcije u društveni poredak, onda se stvara politički efekat. Estetski efekat pretpostavlja disidentifikaciju. U estetskoj zajednici, politička subjektivizacija se zasniva na procesu disidentifikacije. Osim toga, ponovno razmatranje modernosti za Ransijera znači vraćanje na Šilerovu ideju estetskog obrazovanja čoveka koje je nastalo u Kantovoj Analitici lepog. Možemo raspravljati sa pozivanjem na arhitekturu neslaganja da kroz proces dislokacije, raspadanja i disidentifikacije, tradicija se otvara stalnoj transformaciji u nešto novo, uključeno u beskrajnu igru između potpuno različitih slojeva koji čine svakodnevno iskustvo. 